\title{
Data report: crystallographic-preferred orientations determined by electron backscattered diffraction in isotropic gabbroic rocks from the sheeted dike/gabbro transition zone in superfast spread crust, ODP Hole 1256D ${ }^{1}$
}

Jeremy Deans ${ }^{2}$ and Benoît lldefonse ${ }^{3}$

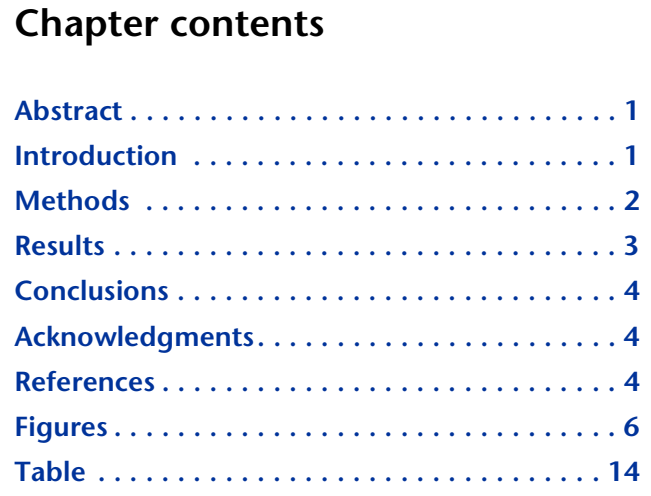

1Deans, J., and Ildefonse, B., 2016. Data report: crystallographic-preferred orientations determined by electron backscattered diffraction in isotropic gabbroic rocks from the sheeted dike/gabbro transition zone in superfast spread crust, ODP Hole 1256D. In Teagle, D.A.H., Ildefonse, B., Blum, P., and the Expedition 335 Scientists, Proceedings of the Integrated Ocean Drilling Program, 335: Tokyo (Integrated Ocean Drilling Program Management International, Inc.).

doi:10.2204/iodp.proc.335.204.2016

2Department of Geosciences, Texas Tech

University, Lubbock TX 79409, USA.

jeremy.deans@ttu.edu

${ }^{3}$ Géosciences Montpellier, Université de

Montpellier, 34095 Montpellier Cedex 5, France.

\section{Abstract}

Ocean Drilling Program (ODP) Hole 1256D is the first in situ penetration into the sheeted dike/gabbro transition zone and was drilled over the course of several expeditions. The hole was initiated during ODP Leg 206 and lengthened during Integrated Ocean Drilling Program Expeditions 309, 312, and 335. Nine samples were analyzed from two gabbroic sections (Gabbros 1 and 2) recovered from Expedition 312 for crystallographic-preferred orientation of plagioclase, clinopyroxene, olivine, and orthopyroxene. Plagioclase and clinopyroxene are the focus of this study because these two phases are the most modally abundant minerals. Our results are compared with shape-preferred orientations from the same samples. The results demonstrate the absence of crystallographic-preferred orientation in any phases analyzed. Even though the nature of the sheeted dike/gabbro transition zone is still poorly constrained, our results are similar to those reported in rocks that have been interpreted to represent the crystallized axial melt lens in the Oman ophiolite.

\section{Introduction}

Ocean Drilling Program (ODP) Hole 1256D is the first complete penetration of the upper oceanic crust reaching the uppermost part of the gabbroic lower crust. Hole 1256D was drilled between ODP Leg 206 (Shipboard Scientific Party, 2003) and Integrated Ocean Drilling Program Expeditions 309 and 312 (Expedition 309/312 Scientists, 2006) and 335 (Expedition 335 Scientists, 2012). Hole $1256 \mathrm{D}$ is located in $3635 \mathrm{~m}$ of water in the Guatemala Basin $\left(6^{\circ} 44.2^{\prime} \mathrm{N}, 91^{\circ} 56.1^{\prime} \mathrm{W}\right)$ on 15 Ma oceanic crust of the Cocos plate, which formed along the East Pacific Rise at a full spreading rate of $>200 \mathrm{~mm} / \mathrm{y}$ (Wilson, 1996). Below a $250 \mathrm{~m}$ thick section of sedimentary cover, $810 \mathrm{~m}$ of lavas and $346 \mathrm{~m}$ of sheeted dikes were penetrated with recovery between $5 \%$ and $30 \%$. The first gabbroic rocks were encountered at 1407 meters below seafloor (mbsf) during Expedition 312. The recovered crustal section is characterized by a $115 \mathrm{~m}$ thick dike-gabbro transition zone that includes two $\sim 52$ and $\sim 12 \mathrm{~m}$ thick gabbro intervals intruded into diabase dikes with granoblastic textures (Fig. F1) (Wilson et al., 2006; Expedition 335 Scientists, 2012; Ildefonse et al., 2014). 
The gabbroic rocks from the two gabbro intervals (Gabbros 1 and 2; Fig. F1) are isotropic, referred to as "varitextured," and are similar to those described at the same level of the crustal section exposed in the Oman ophiolite (e.g., MacLeod and Yaouancq, 2000; France et al., 2009). These gabbros potentially represent the top of the crystallized axial melt lens (Wilson et al., 2006; Koepke et al., 2008, 2011; France et al., 2009; Alt et al., 2010). The gabbroic bodies have been interpreted as relatively small intrusive bodies rooting into a larger melt lens below (Koepke et al., 2008; Alt et al., 2010). Another interpretation is the gabbroic bodies represent the main melt lens in which the granoblastic diabases between Gabbros 1 and 2 and those below Gabbro 2 represent large stoped enclaves of sheeted dikes (France et al., 2009).

We present here an analysis of the crystallographicpreferred orientations (CPO) of the most abundant primary silicate phases (plagioclase and clinopyroxene) in 9 samples from the Gabbro 1 and 2 intervals to document the variability of their magmatic fabrics. Seven of the nine measured samples (Table T1) were also used by Trela et al. (2015) for shapepreferred orientation (SPO) measurements of plagioclase. The samples used in this study are from 1412.99-1494.36 mbsf in Cores 312-U1256D-214R through 232R. All samples have textures that are essentially isotropic, with tabular plagioclase, subophitic clinopyroxene, minor orthopyroxene, Fe-Ti oxides, and olivines. Secondary amphibole is abundant. Some samples (e.g., 312-U1256D-231R-1, 92$94 \mathrm{~cm}$ ) have anorthositic domains characterized by lower proportions of clinopyroxene and smaller grain size than the surrounding rock. Other samples contain veins filled with chlorite (e.g., 220R-1, 14-17 $\mathrm{cm}$ ) and/or amphibole (e.g., 223R-2, 7-9 cm).

\section{Methods}

Plagioclase and clinopyroxene CPOs were measured using the electron backscatter diffraction (EBSD) technique (e.g., Prior et al., 2009) using two scanning electron microscopes (SEM) at the University of Montpellier, France: a JEOL JSM-5600 and CamScan 500XE crystal probe. Both systems are equipped with Oxford/Nordlys EBSD detectors; the diffraction patterns were collected and processed using the Channel 5 suite of programs. The JSM-5600 and crystal probe were used at accelerating voltages of 15 and 20 $\mathrm{kV}$, respectively, and a working distance of $25 \mathrm{~mm}$. Crystallographic orientation maps were obtained for each sample, scanning the thin section by moving the stage with step sizes ranging from 21 to $60 \mu \mathrm{m}$.
The step sizes are at least 10 times smaller than the grain size of the phases of interest. The indexing rate (fraction of patterns that are automatically indexed during mapping) ranges from $\sim 50 \%$ to $80 \%$ in the raw maps. We use the HKL reference data files to index olivine, clinopyroxene, and orthopyroxene and an in-house (Géosciences Montpellier, France) reference data file to index plagioclase. The raw data contain all indexed pixels with a mean angular deviation (MAD; i.e., the angle between the acquired diffraction pattern and the indexing solution proposed by the software) of $<1.3^{\circ}$. The first stage of postacquisition data processing was done using the Tango software of the Channel 5 suite to increase the quality of the maps, consisting of removing isolated pixels that are either nonindexed or indexed as a given phase and surrounded by pixels indexed for another phase and filling nonindexed pixels that have a minimum of 5 neighboring pixels with the same orientation.

EBSD data sets were then processed using MTEX (version 4.0.23), a free Matlab toolbox for analyzing and modeling crystallographic orientation (http://mtextoolbox.github.io) (Hielscher and Schaeben, 2008; Bachmann et al., 2010). We used MTEX to identify grains and produce maps from the EBSD data, calculate pole figures of the plagioclase and clinopyroxene preferred orientation, analyze the crystallographic misorientations within grains, and calculate CPO strength and shape indexes.

Grains were identified from the EBSD data by choosing a $10^{\circ}$ threshold. If the misorientation between two adjacent pixels of the same phase is $>10^{\circ}$, then it is assumed a grain boundary is present. Grains that have a surface $<5$ pixels could be erroneous measurements and were removed from the data set. Twins in both plagioclase and clinopyroxene were distinguished from grain boundaries by filtering out the $178^{\circ}-180^{\circ}$ misorientations in grain boundary identification. Pole figures were calculated using both the grid data set from EBSD mapping (grid data) and the average crystallographic orientation for each grain (grain data). The second option is preferred to avoid the over-representation of larger grains when the grain size distribution is heterogeneous at the thin section scale.

The CPO strength for each phase is determined using both the orientation distribution function (ODF) Jindex exclusively based on crystallographic orientations (e.g., Bunge, 1982; Mainprice and Silver, 1993), and the M-index (Skemer et al., 2005) based on the misorientation angle distribution across a sample. Jindex values vary between 1 (for a uniform distribu- 
tion) to infinity (for a single crystal); M-index values vary from 0 to 1 (see Mainprice et al., 2014, for the details of J- and M-index calculations and for a comparison between these two indexes). The ODF was calculated using the "de la Vallee Poussin" kernel with a half-width of $10^{\circ}$ (Schaeben, 1999; Mainprice et al., 2014).

Symmetry of the CPOs is determined using the BAand $\mathrm{BC}$-indexes, which are calculated from the point $(P)$, girdle $(G)$, and random $(R)$ indexes, which are calculated from eigenvalues $\left(\lambda_{1} \geq \lambda_{2} \geq \lambda_{3}\right.$, with $\lambda_{1}+\lambda_{2}$ $\left.+\lambda_{3}=1\right)$ of the orientation tensor for each pole figure (Vollmer, 1990; Satsukawa et al., 2013; Mainprice et al., 2014):

$$
\begin{gathered}
P=\lambda_{1}-\lambda_{3}, G=2\left(\lambda_{2}-\lambda_{3}\right), R=3 \lambda_{3} ; \\
\mathrm{BA}=1 / 2\left\{2-\left[P_{(010)} /\left(G_{(010)}+P_{(010)}\right)\right]-\left[P_{[100]} /\left(G_{[100]}+P_{[100]}\right)\right]\right\},
\end{gathered}
$$

and

$$
\mathrm{BC}=1 / 2\left\{2-\left[P_{(010)} /\left(G_{(010)}+P_{(010)}\right)\right]-\left[P_{[001]} /\left(G_{[001]}+P_{[001]}\right)\right]\right\} .
$$

In a plagioclase $\mathrm{CPO}$ resulting from magmatic flow, foliation is classically marked by a preferred orientation of [010] planes and lineation by a preferred orientation of [100] axes (Satsukawa et al., 2013). The BA-index is 0 for a perfect axial-B CPO, an oblate (planar) fabric, and is 1 for a perfect axial-A CPO, a prolate (linear) fabric. With pyroxene, the results are similar, except that magmatic lineation is marked by the preferred orientation of [001] axes. Hence, we use the $\mathrm{BC}$-index to characterize the variations between a perfect oblate $(\mathrm{BC}=0)$ and a perfect prolate $(\mathrm{BC}=1) \mathrm{CPO}$.

In EBSD maps produced using MTEX, the misorientation within the grains is quantified using two parameters, the misorientation to the mean (M2M), and the kernel average misorientation (KAM). The $\mathrm{M} 2 \mathrm{M}$ gives, for each pixel within a grain, the angle between the crystallographic orientation of that pixel and the average crystallographic orientation of the grain. The M2M allows for the visualization of the misorientation between domains separated by subgrain boundaries or the progressive misorientation related to undulose extinction in optical microscopy. The KAM is, for each pixel, the average misorientation $\left(<10^{\circ}\right)$ of the nearest $N$ pixel neighbors within a crystal $(N=4$ here; see Wright et al., 2011, for a review of misorientation parameters).

\section{Results}

Three examples of EBSD maps are shown in Figures F2, F3, and F4. The index rate is not optimal in these samples because of the relative abundance of secondary phases (e.g., amphiboles and chlorite), which were not systematically indexed in all measurement runs. These three examples are representative of all measurements presented herein; there is no significant misorientation in the grains shown by either M2M or KAM, attesting to the magmatic nature of the textures in these samples. Figure F5 displays the misorientation histograms for Samples 312-U1256D223R-2, $120 \mathrm{~cm}$, and 232R-2, $38 \mathrm{~cm}$ (Figs. F3, F4). As in all samples, the misorientation in clinopyroxene grains is a bit higher (19\% on average between $2^{\circ}$ and $\left.20^{\circ}\right)$ than in plagioclase grains $(3 \%$ on average between $2^{\circ}$ and $20^{\circ}$ ). The inverse pole figures for misorientation angles between $2^{\circ}$ and $20^{\circ}$ (Fig. F5) show that the preferred rotation axes are [001] and [100] in plagioclase and [010] in clinopyroxene. These are consistent with minor plastic deformation, resulting from the activation of the [001](010) and [100](001) slip systems in plagioclase (e.g., Montardi and Mainprice, 1987; Stünitz et al., 2003) and of the [001](100) slip system in clinopyroxene (e.g., Bascou et al., 2002).

Grid data and grain data pole figures are displayed in Figures F6 and F7, respectively. None of the 9 measured samples show any significant CPO. The first eigenvector of the orientation tensor in each pole figure varies greatly in direction from one sample to the other with no systematic trend downhole (Figs. F6, F7). CPO strength, quantified by the J- and M-indexes, is always very low (Table T1; Fig. F1). Note that $\mathrm{J}$ values can be abnormally high (italic in Table T1) when the grain number is low enough that the ODF calculation is statistically meaningless (e.g., clinopyroxenes in Sample 215R-2, $77 \mathrm{~cm}$ ) (Fig. F2) or when one or a few large grains dominate the signal in grid data (e.g., plagioclase in Sample 222R-1, 142 $\mathrm{cm})$. These effects are particularly strong for very weak CPOs. The absence of significant CPO is confirmed by the almost perfect match in the misorientation histograms between the misorientation distribution curves calculated for a theoretical uniform distribution (i.e., no fabric) and for uncorrelated pixels (Fig. F5). Any significant CPO should produce an uncorrelated pixel misorientation curve that is different from the uniform distribution curve. The shape of symmetry of the CPOs, quantified here with the BA (plagioclase) and BC (clinopyroxene) indexes logically do not reveal significant deviation from a circular shape of the 3-D fabric ellipsoid (Table T1; Fig. F2). Both indexes are close to 0.5 on average, with a slight tendency for a prolate shape in plagioclase $\left(\mathrm{BA}_{\text {mean }}=0.56\right.$ for grid data and 0.58 for grain data) and for an oblate shape in clinopyroxene $\left(\mathrm{BC}_{\text {mean }}=0.43\right.$ for grid data and 0.46 for grain data $)$. 
The SPO of plagioclase measured by Trela et al. (2015) using the "intercept" image analysis method (Launeau and Robin, 1996) does not correlate with the CPO intensity measured from EBSD maps on the same samples (Fig. F8). For example, Sample 232R-2, $38-40 \mathrm{~cm}$, has one of the highest SPO intensities in Trela et al. (2015), whereas it has one of the lowest J values in this study (Table T1). The decrease in SPO intensity in the upper part of Gabbro 1 documented by Trela et al. (2015) is not confirmed by our results; the two CPOs measured in the same interval ( 14101420 mbsf) show an opposite trend (Fig. F1).

\section{Conclusions}

CPO measurements and analysis presented herein show that gabbroic rocks in the Gabbro 1 and 2 intervals do not exhibit significant crystallographic fabrics; hence, there is no record in the crystallographic data to suggest significant magmatic flow in these gabbroic intrusions. Trela et al. (2015) reported "distinct and consistent" plagioclase SPO in samples Gabbros 1 and 2; however, this is not confirmed by the results presented here. Our results are consistent with textures observed (i.e., no preferred shape or crystallographic orientation) in ophiolites at the sheeted dike complex-fossilized melt lens transition zone (e.g., MacLeod and Yaouancq, 2000; France et al., 2009). However, this study cannot further constrain the structural context of Gabbros 1 and 2 within this transition zone.

\section{Acknowledgments}

This research used samples and/or data provided by the Integrated Ocean Drilling Program (IODP). We thank the crew of the R/V JOIDES Resolution and the IODP United States Implementing Organization's technical staff for their outstanding work during Expedition 335. We thank Fabrice Barou for assistance with EBSD analysis, David Mainprice for his invaluable advice on using MTEX, and Eric Ferre for making his thin sections available. We also thank Jill A. VanTongeren for her input on the manuscript. This work was supported by a postexpedition activity award from the USSSP for Aaron Yoshinobu and Jeremy Deans.

\section{References}

Alt, J.C., Laverne, C., Coggon, R.M., Teagle, D.A.H., Banerjee, N.R., Morgan, S., Smith-Duque, C.E., Harris, M., and Galli, L., 2010. Subsurface structure of a submarine hydrothermal system in ocean crust formed at the East
Pacific Rise, ODP/IODP Site 1256. Geochemistry, Geophysics, Geosystems, 11(10):Q10010. http://dx.doi.org/ 10.1029/2010GC003144

Bachmann, F., Hielscher, R., and Schaeben, H., 2010. Texture Analysis with MTEX - free and open source software toolbox. Solid State Phenomena, 160:63-68. http:// dx.doi.org/10.4028/www.scientific.net/SSP.160.63

Bascou, J., Tommasi, A., and Mainprice, D., 2002. Plastic deformation and development of clinopyroxene lattice preferred orientations in eclogites. Journal of Structural Geology, 24(8):1357-1368. http://dx.doi.org/10.1016/ S0191-8141(01)00137-7

Bunge, H.-J., 1982. Texture Analysis in Materials Sciences, Mathematical Methods: Butterworth (London).

Expedition 309/312 Scientists, 2006. Expedition 309/312 summary. In Teagle, D.A.H., Alt, J.C., Umino, S., Miyashita, S., Banerjee, N.R., Wilson, D.S., and the Expedition 309/312 Scientists. Proceedings of the Integrated Ocean Drilling Program, 309/312: Washington, DC (Integrated Ocean Drilling Program Management International, Inc.). http://dx.doi.org/10.2204/ iodp.proc.309312.101.2006

Expedition 335 Scientists, 2012. Expedition 335 summary. In Teagle, D.A.H., Ildefonse, B., Blum, P., and the Expedition 335 Scientists, Proceedings of the Integrated Ocean Drilling Program, 335: Tokyo (Integrated Ocean Drilling Program Management International, Inc.). http:// dx.doi.org/10.2204/iodp.proc.335.101.2012

France, L., Ildefonse, B., and Koepke, J., 2009. Interactions between magma and hydrothermal system in Oman ophiolite and in IODP Hole 1256D: fossilization of a dynamic melt lens at fast spreading ridges. Geochemistry, Geophysics, Geosystems, 10(10):Q10O19. http:// dx.doi.org/10.1029/2009GC002652

Hielscher, R., and Schaeben, H., 2008. A novel pole figure inversion method: specification of the MTEX algorithm. Journal of Applied Crystallography, 41(6):1024-1037. http://dx.doi.org/10.1107/S0021889808030112

Ildefonse, B., Abe, N., Godard, M., Morris, A., Teagle, D.A.H., and Umino, S., 2014. Formation and evolution of oceanic lithosphere: new insights on crustal structure and igneous geochemistry from ODP/IODP Sites 1256, U1309, and U1415. In Stein, R., Blackman, D.K., Inagaki, F., and Larsen, H.-C. (Eds.), Earth and Life Processes Discovered From Subseafloor Environments-A Decade of Science Achieved by the Integrated Ocean Drilling Program (IODP). Developments in Marine Geology, 7:49505. http://dx.doi.org/10.1016/B978-0-444-626172.00017-7

Koepke, J., Christie, D.M., Dziony, W., Holtz, F., Lattard, D., Maclennan, J., Park, S., Scheibner, B., Yamasaki, T., and Yamazaki, S., 2008. Petrography of the dike-gabbro transition at IODP Site 1256 (equatorial Pacific): the evolution of the granoblastic dikes. Geochemistry, Geophysics, Geosystems, 9(7):Q07O09. http://dx.doi.org/ 10.1029/2008GC001939

Koepke, J., France, L., Müller, T., Faure, F., Goetze, N., Dziony, W., and Ildefonse, B., 2011. Gabbros from IODP Site 1256, equatorial Pacific: insight into axial magma 
chamber processes at fast spreading ocean ridges. Geochemistry, Geophysics, Geosystems, 12(9):Q09014. http:// dx.doi.org/10.1029/2011GC003655

Launeau, P., and Robin, P.-Y.F., 1996. Fabric analysis using the intercept method. Tectonophysics, 267(1-4):91-119. http://dx.doi.org/10.1016/S0040-1951(96)00091-1

MacLeod, C.J., and Yaouancq, G., 2000. A fossil melt lens in the Oman ophiolite: implications for magma chamber processes at fast spreading ridges. Earth and Planetary Science Letters, 176(3-4):357-373. http://dx.doi.org/ 10.1016/S0012-821X(00)00020-0

Mainprice, D., Bachmann, F., Hielscher, R., and Schaeben, H., 2014. Descriptive tools for the analysis of texture projects with large data sets using MTEX: strength, symmetry and components. Geological Society, Special Publications. 409:251-271. http://dx.doi.org/10.1144/ SP409.8

Mainprice, D., and Silver, P.G., 1993. Interpretation of SKSwaves using samples from the subcontinental lithosphere. Physics of the Earth and Planetary Interiors, 78(34):257-280. http://dx.doi.org/10.1016/00319201(93)90160-B

Montardi, Y., and Mainprice, D., 1987. A transmission electron microscopic study of the natural plastic deformation of calcific plagioclases (An $68 \pm 70$ ). Bulletin Mineralogique, 110:1-14.

Prior, D.J., Mariani, E., and Wheeler, J., 2009. EBSD in the earth sciences: applications, common practice, and challenges. In Schwartz, A.J., Kumar, M., Adams, B.L., and Field, D.P. (Eds.), Electron Backscatter Diffraction in Materials Science (2nd edition): Springer Science and Business Media (New York), 345-360. http://dx.doi.org/ 10.1007/978-0-387-88136-2

Satsukawa, T., Ildefonse, B., Mainprice, D., Morales, L.F.B., Michibayashi, K., and Barou, F., 2013. A database of plagioclase crystal preferred orientations $(\mathrm{CPO})$ and microstructures-implications for CPO origin, strength, symmetry and seismic anisotropy in gabbroic rocks. Solid Earth, 4:511-542. http://dx.doi.org/10.5194/se4-511-2013

Schaeben, H., 1999. The de la Vallée Poussin standard orientation density function. Textures and Microstructures, 33(1-4):365-373. http://dx.doi.org/10.1155/

TSM.33.365

Shipboard Scientific Party, 2003. Leg 206 summary. In Wilson, D.S., Teagle, D.A.H., Acton, G.D., Proceedings of the Ocean Drilling Program, Initial Reports, 206: College Station, TX (Ocean Drilling Program), 1-117. http:// dx.doi.org/10.2973/odp.proc.ir.206.101.2003
Skemer, P., Katayama, I., Jiang, Z., and Karato, S.-I., 2005. The misorientation index: development of a new method for calculating the strength of lattice-preferred orientation. Tectonophysics, 411(1-4):157-167. http:// dx.doi.org/10.1016/j.tecto.2005.08.023

Stünitz, H., Fitz Gerald, J.D., and Tullis, J., 2003. Dislocation generation, slip systems, and dynamic recrystallization in experimentally deformed plagioclase single crystals. Tectonophysics, 372(3-4):215-233. http:// dx.doi.org/10.1016/S0040-1951(03)00241-5

Trela, J., Ferré, E.C., Launeau, P., Bartz, D.M., and Morris, A., 2015. Magmatic accretion and thermal convection at the sheeted dike complex-gabbro boundary in superfast spreading crust, ODP Hole 1256D. Tectonophysics, 660:107-116. http://dx.doi.org/10.1016/ j.tecto.2015.08.023

Vollmer, F.W., 1990. An application of eigenvalue methods to structural domain analysis. Geological Society of America Bulletin, 102(6):786-791. http://dx.doi.org/ 10.1130/0016-7606(1990)102<0786:aaoemt $>2.3 . c 0 ; 2$

Wilson, D.S., 1996. Fastest known spreading on the Miocene Cocos-Pacific plate boundary. Geophysical Research Letters, 23(21):3003-3006. http://dx.doi.org/10.1029/ 96GL02893

Wilson, D.S., Teagle, D.A.H., Alt, J.C., Banerjee, N.R., Umino, S., Miyashita, S., Acton, G.D., Anma, R., Barr, S.R., Belghoul, A., Carlut, J., Christie, D.M., Coggon, R.M., Cooper, K.M., Cordier, C., Crispini, L., Durand, S.R., Einaudi, F., Galli, L., Gao, Y., Geldmacher, J., Gilbert, L.A., Hayman, N.W., Herrero-Bervera, E., Hirano, N., Holter, S., Ingle, S., Jiang, S., Kalberkamp, U., Kerneklian, M., Koepke, J., Laverne, C., Vasquez, H.L.L., Maclennan, J., Morgan, S., Neo, N., Nichols, H.J., Park, S.-H., Reichow, M.K., Sakuyama, T., Sano, T., Sandwell, R., Scheibner, B., Smith-Duque, C.E., Swift, S.A., Tartarotti, P., Tikku, A.A., Tominaga, M., Veloso, E.A., Yamasaki, T., Yamazaki, S., and Ziegler, C., 2006. Drilling to gabbro in intact ocean crust. Science, 312(5776):1016-1020. http://dx.doi.org/10.1126/science. 1126090

Wright, S.I., Nowell, M.M., and Field, D.P., 2011. A review of strain analysis using electron backscatter diffraction. Microscopy and Microanalysis, 17(3):316-329. http:// dx.doi.org/10.1017/s1431927611000055

Initial receipt: 7 September 2015

Acceptance: 5 July 2016

Publication: 6 September 2016

MS 335-204 
Figure F1. Lithostratigraphy overview of the upper-lower crust transition recovered in Hole 1256D (Expedition 335 Scientists, 2012) and depth variations of plagioclase J- and BA-indexes (grain data). ODF = orientation distribution function.

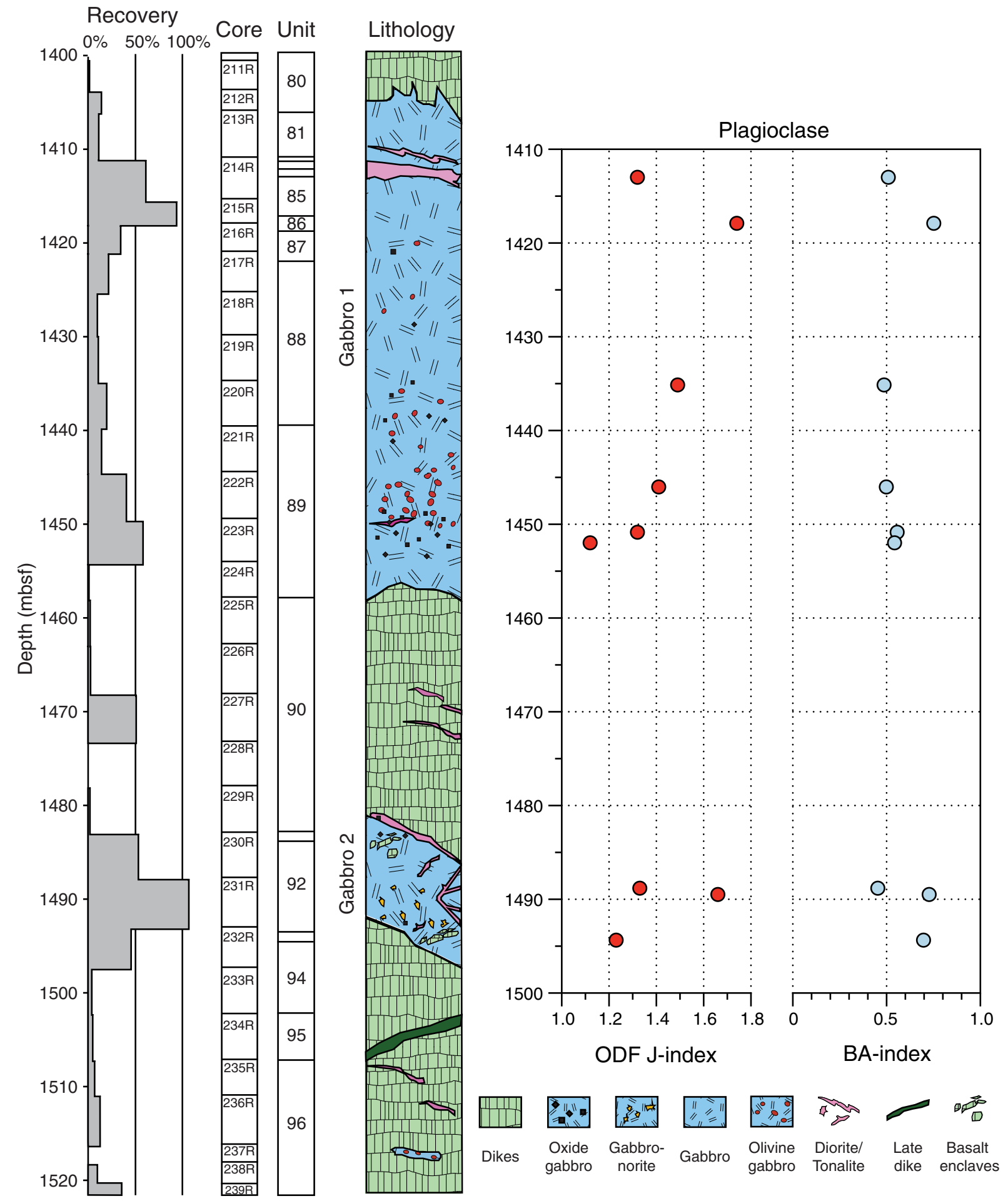


Figure F2. Electron backscatter diffraction maps for Sample 312-U1256D-215R-2, 77-79 cm. See text for further explanation. A. Indexed phases. B, C. Orientation. Color scale indicates the minimum angle between the measured pixel and the reference $(0,0,0)$ Euler orientation. D, E. Misorientation to grain mean. F, G. Kernel average misorientation.
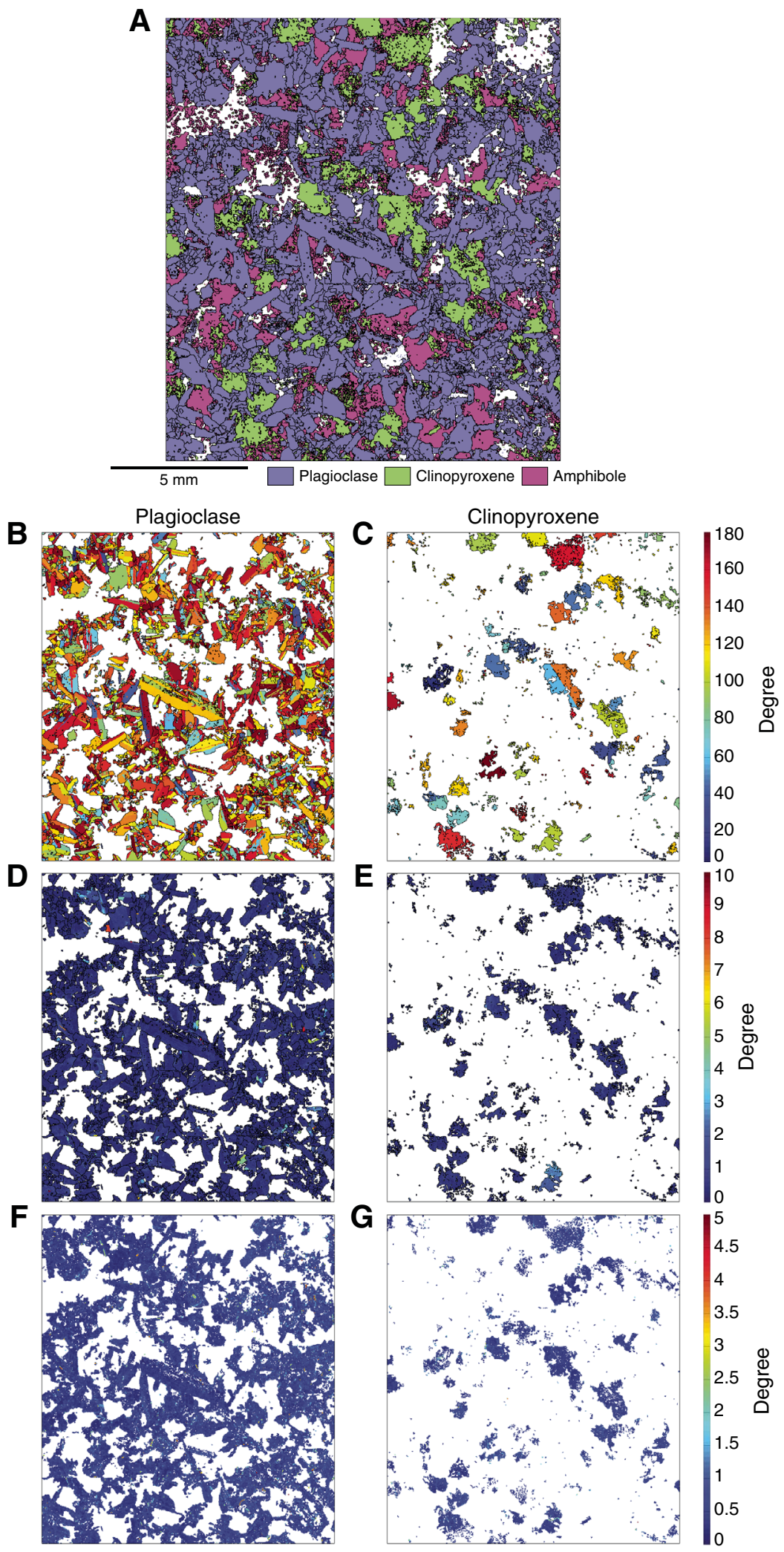
Figure F3. Electron backscatter diffraction maps for Sample 312-U1256D-223R-2, 120-122 cm. See text for further explanation. A. Indexed phases. B, C. Orientation. Color scale indicates the minimum angle between the measured pixel and the reference $(0,0,0)$ Euler orientation. D, E. Misorientation to grain mean. F, G. Kernel average misorientation.
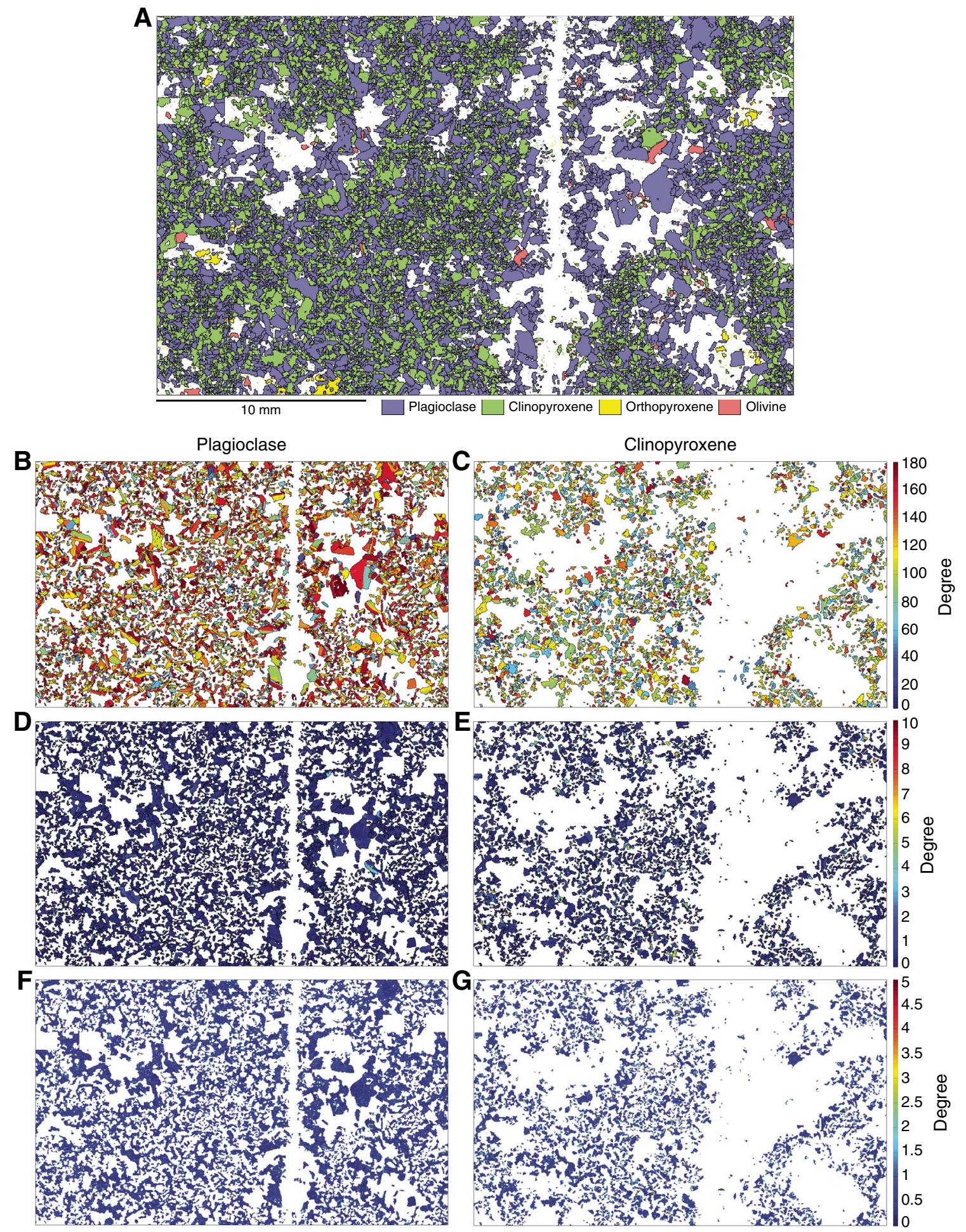
Figure F4. Electron backscatter diffraction maps for Sample 312-U1256D-232R-2, 38-40 cm. See text for further explanation. A. Indexed phases. B, C. Orientation. Color scale indicates the minimum angle between the measured pixel and the reference $(0,0,0)$ Euler orientation. D, E. Misorientation to grain mean. F, G. Kernel average misorientation.
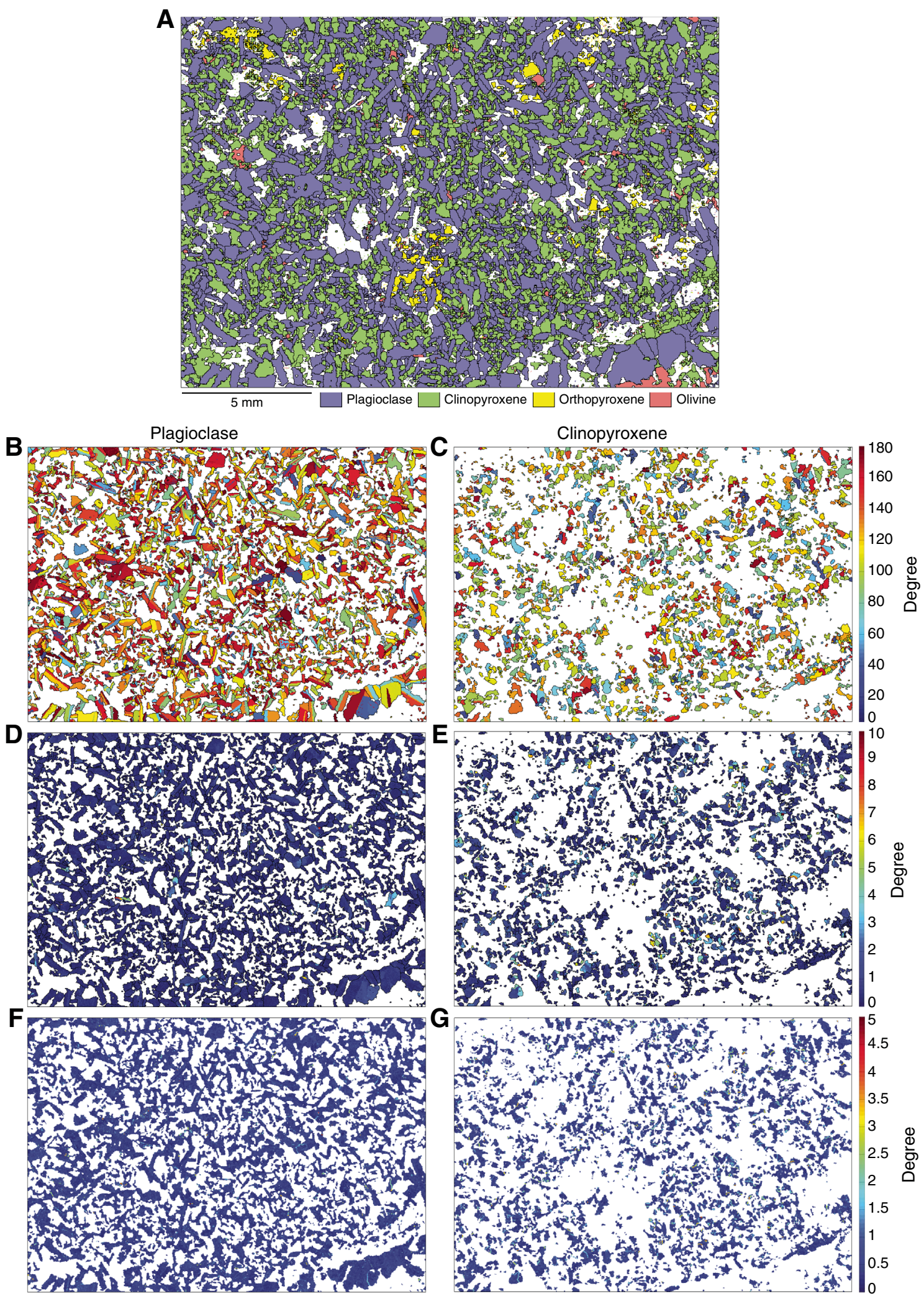
Figure F5. Misorientation distribution for Samples 312-U1256D-223R-2, 120-122 cm, and 232R-2, 38-40 cm. Inverse pole figures show preferred orientation of rotation axes corresponding to misorientations between $2^{\circ}$ and $10^{\circ}$.
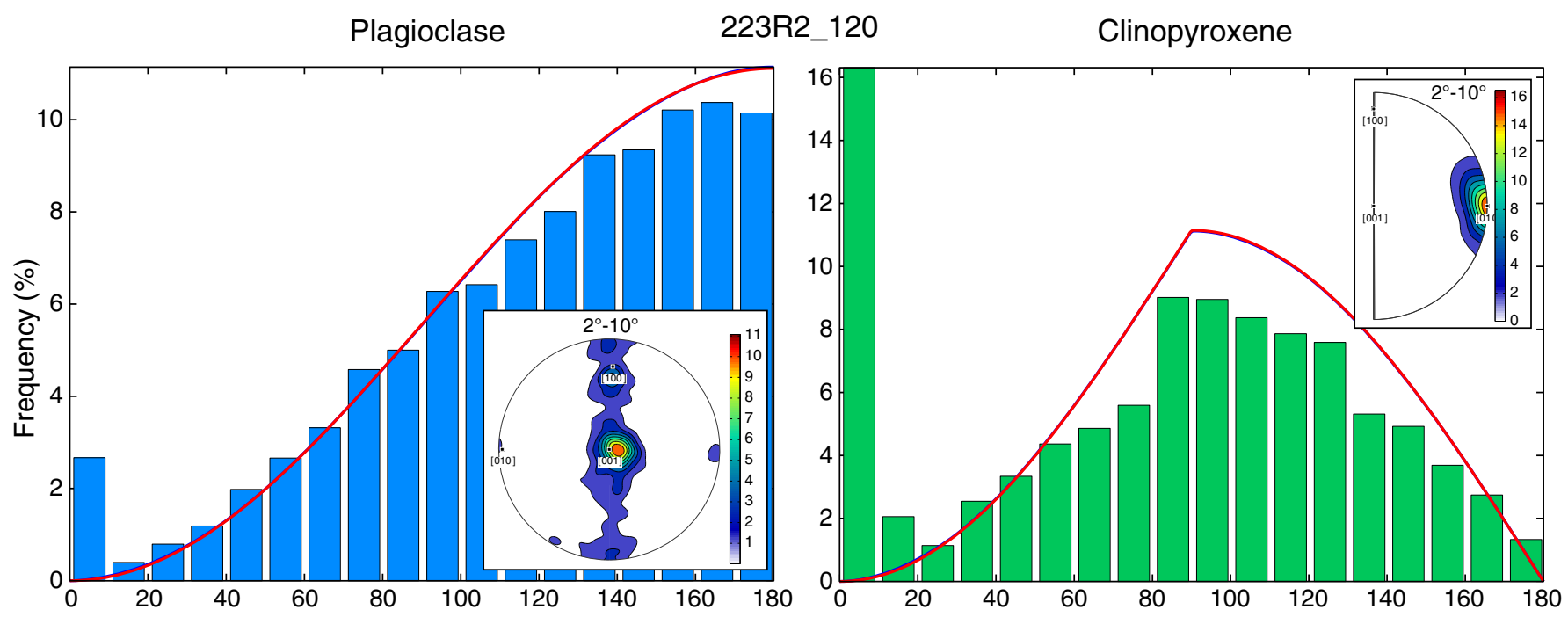

232R2_38
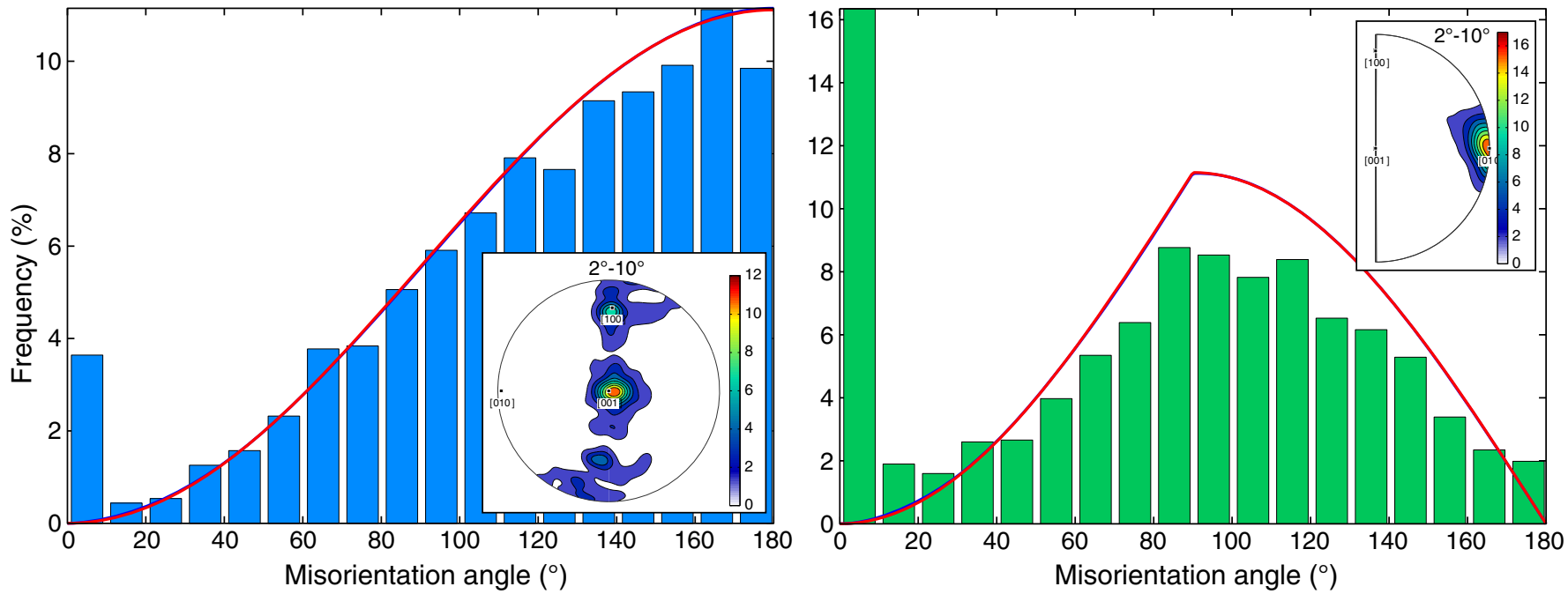

Correlated pixels

Correlated pixels 
Figure F6. Grid data poles. See text for further explanation. Black squares = orientations of first eigenvector. North poles (black ticks) are parallel to the top of the core.

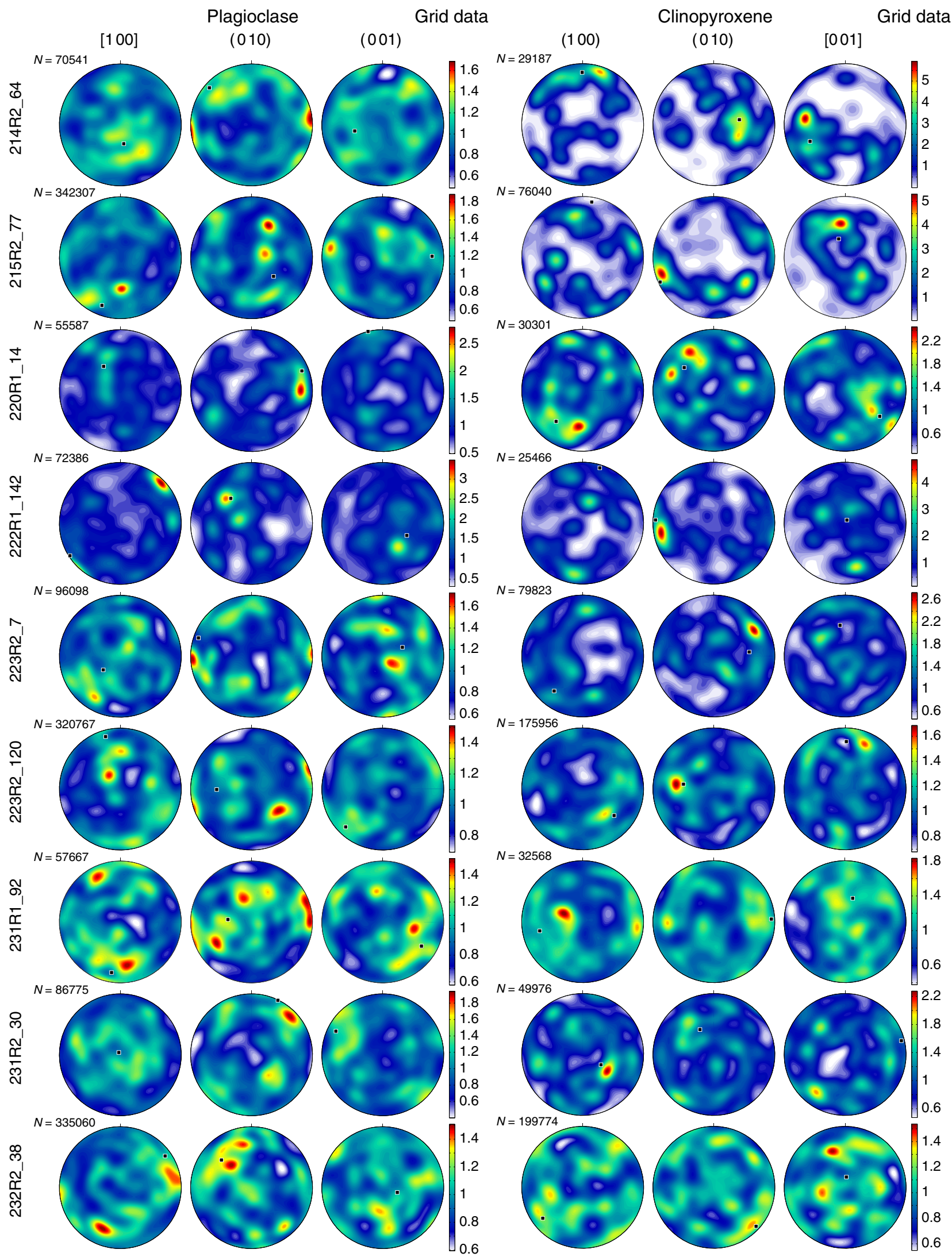


Figure F7. Grain data poles. See text for further explanation. Black squares = orientations of first eigenvector. North poles (black ticks) are parallel to the top of the core.

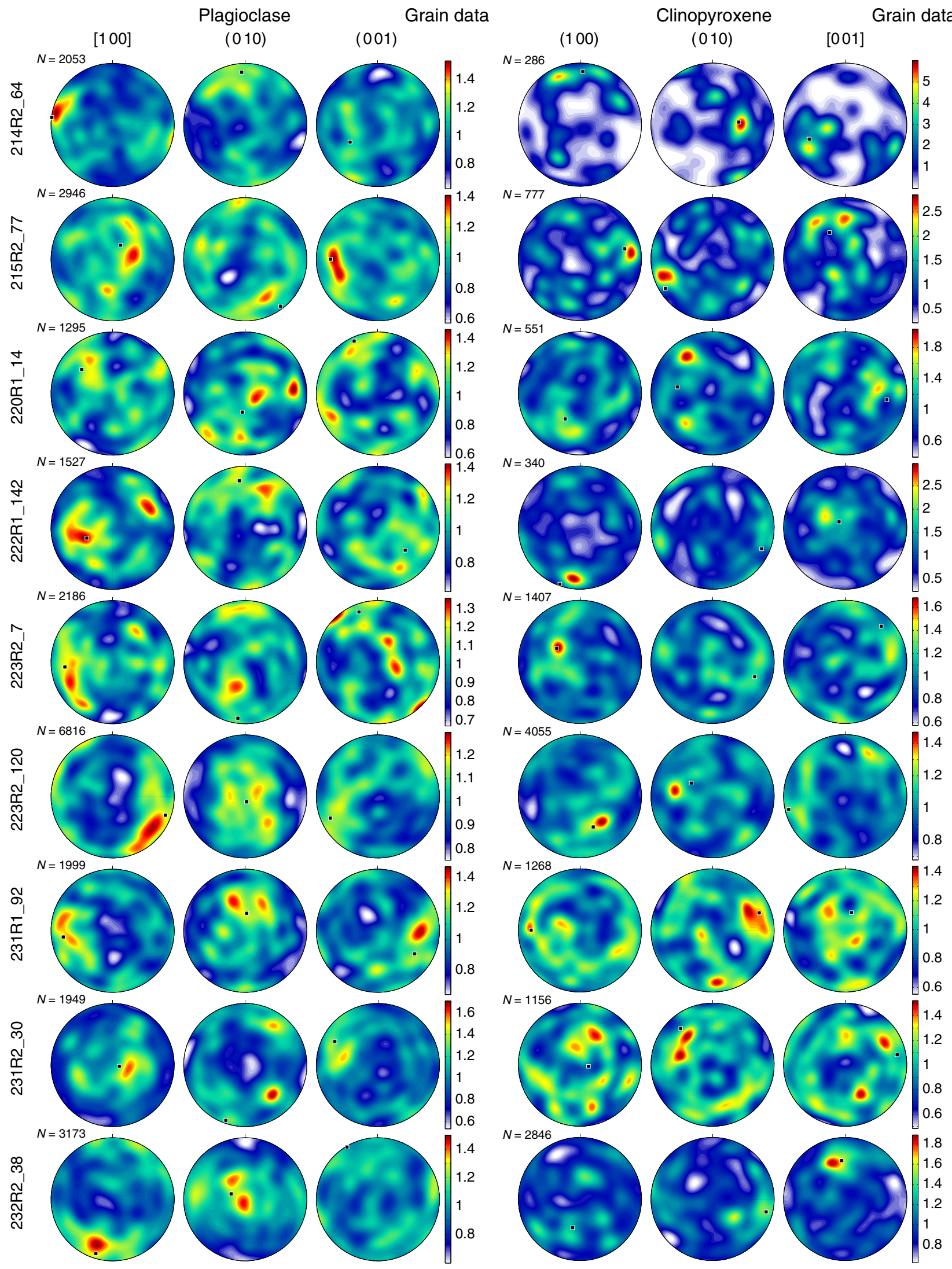


Figure F8. Plot of J-index (grain data) for plagioclase as a function of shape-preferred orientation (axial ratio of the fabric ellipse) in thin sections. See text for further explanation.

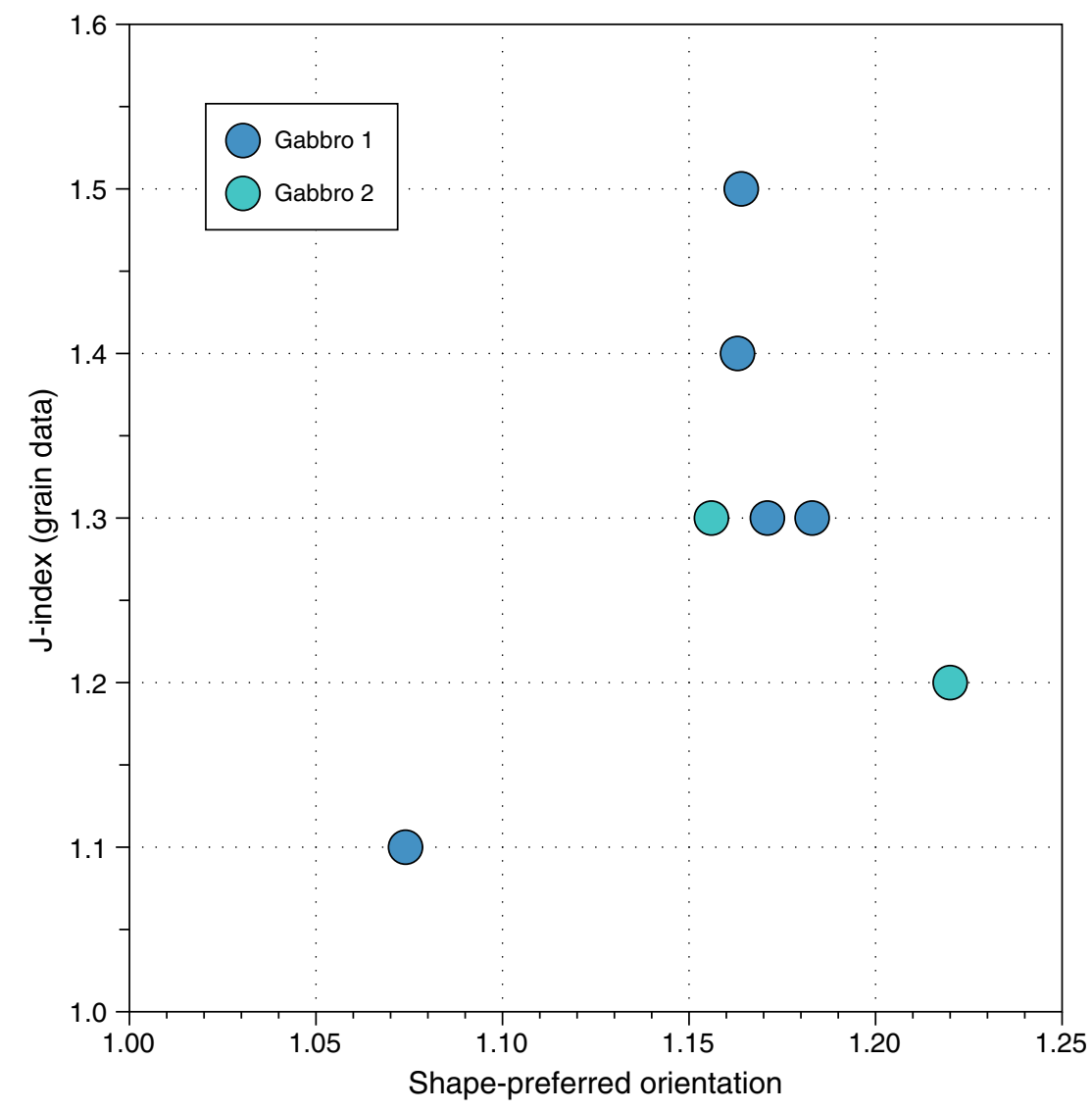


Table T1. Electron backscatter diffraction data, Hole 1256D.

\begin{tabular}{|c|c|c|c|c|c|c|c|c|c|c|c|c|}
\hline \multirow[b]{3}{*}{$\begin{array}{l}\text { Core, section, } \\
\text { interval }(\mathrm{cm})\end{array}$} & \multirow[b]{3}{*}{$\begin{array}{l}\text { Depth } \\
\text { (mbsf) }\end{array}$} & \multirow[b]{3}{*}{ Unit* } & \multirow[b]{3}{*}{ Rock type* } & \multirow{3}{*}{$\begin{array}{c}\text { EBSD } \\
\text { measurement } \\
\text { step size }(\mu \mathrm{m})\end{array}$} & \multicolumn{8}{|c|}{ Plagioclase } \\
\hline & & & & & \multicolumn{3}{|c|}{ Grid data } & \multicolumn{3}{|c|}{ Grain data } & \multirow{2}{*}{$\begin{array}{c}\text { Average } \\
\text { grain size } \\
(\mu \mathrm{m})\end{array}$} & \multirow[b]{2}{*}{$\mathrm{SPO}^{\dagger}$} \\
\hline & & & & & $\begin{array}{l}\text { ODF } \\
\text { J-index }\end{array}$ & M-index & BA-index & $\begin{array}{l}\text { ODF } \\
\text { J-index }\end{array}$ & M-index & BA-index & & \\
\hline \multicolumn{13}{|l|}{ 335-U1256D- } \\
\hline $214 R-2,64-66$ & 1412.99 & 85 & Opx and olivine-bearing oxide gabbro & 50 & 1.5 & 0.002 & 0.74 & 1.3 & 0.002 & 0.51 & 280 & 1.171 \\
\hline 215R-2, 77-79 & 1417.90 & $86 \mathrm{~A}$ & Disseminated oxide gabbro & 20 & 1.7 & 0.002 & 0.52 & 1.7 & 0.004 & 0.75 & 179 & - \\
\hline 220R-1, 14-17 & 1435.14 & $88 \mathrm{~B}$ & Oxide gabbro & 40 & 1.9 & 0.004 & 0.46 & 1.5 & 0.002 & 0.49 & 247 & 1.164 \\
\hline 222R-1, 142-144 & 1446.02 & $89 \mathrm{~A}$ & Opx-bearing olivine gabbro & 60 & 3.1 & 0.010 & 0.49 & 1.4 & 0.002 & 0.50 & 367 & 1.163 \\
\hline $223 \mathrm{R}-2,7-9$ & 1450.85 & $89 \mathrm{~A}$ & Opx-bearing olivine gabbro & 30 & 1.7 & 0.002 & 0.58 & 1.3 & 0.001 & 0.56 & 185 & 1.183 \\
\hline $223 R-2,120-122$ & 1451.98 & $89 \mathrm{C}$ & Opx and olivine-bearing gabbro & 28 & 1.3 & 0.001 & 0.56 & 1.1 & 0.002 & 0.54 & 180 & 1.074 \\
\hline 231R-1, 92-94 & 1488.82 & $92 \mathrm{~A}$ & Disseminated oxide gabbronorite & 60 & 1.5 & 0.004 & 0.67 & 1.3 & 0.003 & 0.45 & 314 & 1.156 \\
\hline $231 \mathrm{R}-2,30-32$ & 1489.49 & $92 \mathrm{~A}$ & Disseminated oxide gabbronorite & 30 & 1.7 & 0.004 & 0.73 & 1.4 & 0.003 & 0.73 & 189 & - \\
\hline $232 \mathrm{R}-2,38-40$ & 1494.36 & $93 \mathrm{~A}$ & Disseminated oxide gabbronorite & 21 & 1.4 & 0.001 & 0.31 & 1.2 & 0.002 & 0.70 & 198 & 1.220 \\
\hline
\end{tabular}

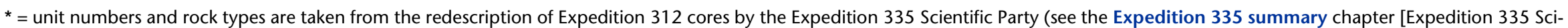

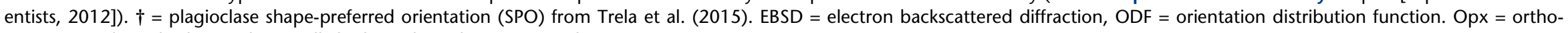
pyroxene. Italicized values $=$ abnormally high $\mathrm{J}$-index values. $-=$ no data.

\begin{tabular}{lcccccccc}
\hline & \multicolumn{9}{c}{ Clinopyroxene } & \\
\cline { 2 - 4 } $\begin{array}{c}\text { Core, section, } \\
\text { interval (cm) }\end{array}$ & $\begin{array}{c}\text { ODF } \\
\text { J-index }\end{array}$ & M-index & BC-index & & $\begin{array}{c}\text { ODF } \\
\text { J-index }\end{array}$ & M-index & BC-index & $\begin{array}{c}\text { Average } \\
\text { grain size } \\
(\mu \mathrm{m})\end{array}$ \\
\hline 335-U1256D- & & & & & & & & \\
215R-2, 77-79 & 8.3 & 0.044 & 0.53 & & 3.5 & 0.010 & 0.45 & 129 \\
220R-1, 14-17 & 2.5 & 0.008 & 0.51 & & 1.7 & 0.003 & 0.29 & 285 \\
222R-1, 142-144 & 4.3 & 0.022 & 0.36 & & 2.5 & 0.010 & 0.48 & 473 \\
223R-2, 7-9 & 1.9 & 0.006 & 0.27 & & 1.3 & 0.002 & 0.47 & 207 \\
223R-2, 120-122 & 1.2 & 0.001 & 0.49 & & 1.1 & 0.001 & 0.30 & 178 \\
231R-1, 92-94 & 1.4 & 0.003 & 0.38 & & 1.3 & 0.001 & 0.59 & 304 \\
231R-2, 30-32 & 1.8 & 0.004 & 0.43 & & 1.4 & 0.002 & 0.54 & 187 \\
232R-2, 38-40 & 1.3 & 0.002 & 0.52 & 1.2 & 0.002 & 0.54 & 166 \\
\hline
\end{tabular}

